\title{
Chromosomal aberrations in mouse lymphocytes exposed in vitro and in vivo to benzidine and 5 related aromatic amines
}

\author{
L. Das ${ }^{\text {a }}$, S.K. Das ${ }^{\text {b }}$, B.H. Hooberman ${ }^{\text {b }}$, E.H.Y. Chu ${ }^{\text {a }}$ and J.E. Sinsheimer ${ }^{\text {b, } *}$ \\ ${ }^{a}$ Department of Human Genetics, Medical School and ${ }^{b}$ College of Pharmacy, University of Michigan, \\ Ann Arbor, MI 48109-1065, USA
}

(Received 21 December 1992)

(Revision received 12 July 1993)

(Accepted 21 July 1993)

Keywords: Aromatic amines; Lymphocyte tests; Chromosomal aberrations

\begin{abstract}
Summary
Mouse lymphocytes were exposed in vitro for $2 \mathrm{~h}$ or in vivo for $24 \mathrm{~h}$ to benzidine and related aromatic amines to test for chromosome aberrations (CA) and mitotic indices. Uninduced mouse S9 was used to activate the amines for the in vitro tests to be consistent with the in vivo tests. Contrary to a previous report, no difference could be established in the genotoxicity of benzidine following activation with uninduced S9 compared to induced S9. There were concentration related increases in CA for benzidine and all the amines in vitro except for 4,4'-diaminostilbene which exhibited the greatest cellular toxicity towards cultured lymphocytes. Benzidine and its derivatives showed significant increases in $\mathrm{CA}$ in vivo compared to its negative control. The CA values for 4-aminostilbene were significantly higher than the other amines in both in vivo and in vitro studies. These genotoxicity results for 4-aminostilbene are consistent with our previous report of the pronounced CA effects in murine bone-marrow cells but would not be predicted from Salmonella mutagenicity tests.
\end{abstract}

Benzidine, because of its bifunctionality and in the case of dyes because of its contribution of extending conjugated unsaturation, was an important intermediate in the polymer and dye industries. However, the restrictions on its continued manufacture and use since its recognition as a human carcinogen (Zavon et al., 1973; Haley, 1975) has led to the utilization of benzidine analogs. Therefore, we have been interested in developing structure-genotoxicity relationships

* Corresponding author. for aromatic amines related to benzidine to aid in making risk assessments of such analogs (Messerly et al., 1987; Sinsheimer et al., 1992; You et al., 1993). In these studies, it was indicated using the Ames Salmonella test that mutagenicity in vitro was promoted by increases in the electronwithdrawing ability of substituents on 4-aminobiphenyl, 4-aminostilbene and 3,3'-disubstituted benzidine derivatives. However, the results with bacteria were not predictive of genotoxicity in vivo, as followed by chromosomal aberrations (CA) in murine bone-marrow cells following intraperitoneal (i.p.) administration of these aro- 
matic amines. The most genotoxic compounds in vivo were the conjugated amines without substituents in the para' position. For example, 4aminostilbene had exceptionally high CA values in vivo which would not have been predicted from the in vitro mutagenicity data.

It is the purpose of the present investigation to extend such studies of the genotoxicity of benzidine and its derivatives by using the same mammalian end-point in vitro and in vivo. In this manner it should be possible to avoid comparing in vitro bacterial to in vivo mammalian results in establishing relative genotoxicity in our series of aromatic amines.

The testing for chromosomal effects in the blood lymphocytes of humans following occupational chemical exposure is well established (Lambert et al., 1982; Galloway et al., 1986). Methods have also been developed to follow chromosomal damage in peripheral blood lymphocytes of rodents following exposure to chemicals in vivo (Kligerman et al., 1982; Rithdech et al., 1987). Cultured human blood lymphocytes after in vitro exposure to chemicals have also been examined for chromosomal damage in the absence of S9 activation (Norppa et al., 1981; Sasiadek et al., 1991) and in the presence of S9 activation (Asquith et al., 1985).

However, we have not been able to find direct comparisons in lymphocytes of chromosomal damage following in vitro versus in vivo exposure to chemicals in laboratory animals. We have previously made that type of comparison for a series of direct-acting epoxide mutagens (Das et al., 1993). In the present study, we needed to extend this approach to a series of aromatic amines that require metabolic activation prior to exhibiting genotoxicity in vitro. A useful starting point for this study is the work of Asquith et al. (1985) where liver S9 fractions were used with the promutagen benzidine to study CA effects in cultured lymphocytes. Thus, in the present investigation, in addition to benzidine, 4-aminobiphenyl, 4-amino-4'-nitrobiphenyl, 4-aminostilbene, 4,4'diaminostilbene and 4-amino-4'-nitrostilbene were examined for CA in mouse lymphocyte cultures following direct in vitro exposure of the amines to the cultures as well as in lymphocyte cultures prepared from mice subsequent to the i.p. administration of these amines. The relative genotoxicity of these amines in vitro compared to that in vivo is of primary interest.

\section{Materials and methods}

\section{Animals}

Male C57BL/6J mice (2-4 months old; $25-30$ g) were obtained from Jackson Laboratory (Bar Harbor, ME) and were provided rodent lab chow (Purina) and water ad libitum. They were kept 5 per cage and housed 4-5 days prior to the start of the experiment. Ambient temperature of the animal room was controlled at $72-74^{\circ} \mathrm{F}$ with relative humidity of $25-50 \%$ and a 12-h photoperiod (light cycle $0600-1800 \mathrm{~h}$ ). Bedding consisted of sterilized hardwood chips (Bed-O'-cobs, Anderson Industrial Products Division, Maumee, $\mathrm{OH}$ ).

\section{Chemicals}

Cyclophosphamide monohydrate (6055-19-2) (CP) and N-acetylaminofluorene (53-96-3) were purchased from Sigma Chemical Co. (St. Louis, MO). Dimethyl sulfoxide (DMSO, 99.9\%) and 4-aminobiphenyl (92-67-1) were obtained from Aldrich Chemical CO. (Milwaukee, WI). Benzidine (4,4'-diaminobiphenyl) (92-87-5) was purchased from Harleco (Philadelphia, PA). 4Amino-4'-nitrobiphenyl (1211-40-1) as well as 4amino-4'-nitrostilbene (7297-52-1), 4-aminostilbene (4309-66-4) and 4,4'-diaminostilbene (731406-9) were synthesized as described earlier (Sinsheimer et al., 1992).

\section{Lymphocyte assays following in vivo exposure}

Amines ( $25 \mathrm{mg} / \mathrm{kg}$ body weight) dissolved in DMSO $(2 \mathrm{ml} / \mathrm{kg})$ were injected i.p. into mice. Because of cell toxicity, 4-aminostilbene was also tested at $10 \mathrm{mg} / \mathrm{kg}$. Negative control mice received only DMSO $(2 \mathrm{ml} / \mathrm{kg})$ and positive control mice were injected with CP $(25 \mathrm{mg} / \mathrm{kg}$ in DMSO). 3 mice were used for each test compound and for the controls with 2 culture tubes prepared from each animal. After $24 \mathrm{~h}$, mice were anesthetized with Metafane (methoxyflurane; Pitman-Moore, Washington, NJ) and blood was drawn by cardiac puncture. Culture tubes were prepared just before inoculation with blood $(0.2 \mathrm{ml})$ following the method of Davisson 
and Akeson (1987). Each culture tube contained $0.95 \mathrm{ml}$ of supplemented medium, $0.15 \mathrm{ml}$ fetal bovine serum (Gibco, Gaithersburg, MD), $0.1 \mathrm{ml}$ of lipopolysaccharide ( $50 \mu \mathrm{g} / \mathrm{ml}$; Sigma) and 0.15 $\mathrm{ml}$ of purified phytohemagglutinin $(60 \mu \mathrm{g} / \mathrm{ml}$; Burroughs Wellcome, Greenville, NC). Supplemented medium was prepared with $100 \mathrm{ml}$ of medium (RPMI 1640; Gibco), $1.2 \mathrm{ml}$ of $200 \mathrm{mM}$ L-glutamine (Gibco) and $1 \mathrm{ml}$ of a mixture of penicillin (100 IU $/ \mathrm{ml})$ and streptomycin (100 $\mu \mathrm{g} / \mathrm{ml}$ ) (Irvine Scientific, Santa Ana, CA).

After inoculation with blood, the tubes were incubated for $42 \mathrm{~h}$ in a humidified $5 \% \mathrm{CO}_{2}$ atmosphere at $37^{\circ} \mathrm{C}$. Colcemid $(0.3 \mu \mathrm{g}$, Sigma $)$ was added 2-3 $\mathrm{h}$ before hypotonic treatment with $\mathrm{KCl}(0.075 \mathrm{M}$ for $20 \mathrm{~min})$. Then the cells were fixed in acetic acid:methanol (1:3). Samples of cell suspensions were added to precleaned slides, air-dried and chromosomes stained with diluted Giemsa (1:20) and evaluated by a single observer. A total of 100 well-spread metaphase figures (50 cells per tube) with $40 \pm 2$ chromosomes per animal were scored according to the criteria of Carrano and Natarajan (1988). Chromosome and chromatid aberrations were scored separately and the total percentage of abnormal cells was expressed for statistical analysis (Sharief et al., 1986). Gaps were recorded but not included in the total CA frequency. Mitotic indices (MI) were estimated from 1000 cells / animal and expressed as percentages. Test chemicals and their controls were run under the same conditions at the same time. Results for the amines were compared to those of their controls using Student's $t$ test.

\section{Lymphocyte assays following in vitro exposure}

Blood was drawn from untreated male mice and added to culture tubes as described above. S9 was prepared from the livers of 5 male mice (C57BL/6J) and the S9 mix made according to the method of Maron and Ames (1983). For benzidine, the activation treatment was both with Aroclor 1254-induced S9 and uninduced S9 mix. All the other amines were treated only with uninduced S9. After $21 \mathrm{~h}$, the original medium was replaced with fresh serum-free medium containing $10 \%$ of the mouse $\mathrm{S} 9$ mixture. Test amines in DMSO $(0.01 \mathrm{ml} / \mathrm{ml}$ medium) were added at the concentrations indicated in Table 1 . After expo- sure for $2 \mathrm{~h}$ with the chemicals in the presence of S9, the cultures were washed 3 times with fresh medium and incubated again for $20 \mathrm{~h}$ under the same conditions as used for the cell cultures obtained following in vivo administration of amines. Culture tubes ( 2 from each of 3 animals) were prepared for each concentration of the amines and for the controls. The negative control was DMSO $(0.01 \mathrm{ml} / \mathrm{ml}$ medium) and the positive control was $N$-acetylaminofluorene $(100 \mu \mathrm{g}$ / $\mathrm{ml}$ ). Scoring and analysis of CA results were as described above for the in vivo exposure experiments. Results at each concentration were compared to those of their negative control using Dunnett's test.

\section{Results and discussion}

The in vitro assay results for benzidine following activation by $\$ 9$ with and without induction by Aroclor 1254 are given in Table 1. Asquith et al. (1985), in their study of CA in human lymphocyte cultures, reported a greater response for activation with uninduced S9 than for induced S9. In the present study with mouse lymphocytes, a concentration-response relationship was found with both treatments but they were not significantly different. All subsequent in vitro comparisons of the amines to benzidine were performed with uninduced S9 to parallel our in vivo tests. The results are given in Table 1 . Benzidine and its derivatives, except for 4,4'-diaminostilbene, produced a significant increase $(p<0.01)$ in the percentage of CA compared to their negative controls and concentration-response relationships could be established for most of these amines. However, toxicity at the higher concentrations is a factor in narrowing this relationship for 4-aminostilbene and the two nitro compounds. Toxicity became most evident when these compounds were tested at $400 \mu \mathrm{g} / \mathrm{ml}$ and there were insufficient metaphase cells for evaluation. 4-Aminostilbene exhibited this toxicity at 200 $\mu \mathrm{g} / \mathrm{ml}$ and $4,4^{\prime}$-diaminostilbene even at $25 \mu \mathrm{g} /$ $\mathrm{ml}$. This latter compound was the only derivative for which CA and MI results could not be established. Toxicity is a limitation in ranking these amines by the in vitro lymphocyte assay in comparison to our previous study (Sinsheimer et al., 
TABLE 1

CHROMOSOMAL ABERRATIONS IN MOUSE LYMPHOCYTE IN VITRO CULTURES INDUCED BY BENZIDINE AND RELATED AMINES

\begin{tabular}{|c|c|c|c|c|c|c|}
\hline \multirow{2}{*}{$\begin{array}{l}\text { Treatment } \\
\text { Dose } \\
(\mu \mathrm{g} / \mathrm{ml})\end{array}$} & \multirow[t]{2}{*}{ Gaps $^{\text {a }}$} & \multicolumn{2}{|c|}{ Aberrations/cell } & \multirow{2}{*}{$\begin{array}{l}\text { Aberrant cells }{ }^{b} \\
(\%)(\text { mean } \pm \text { S.D. })^{d}\end{array}$} & \multirow{2}{*}{$\begin{array}{l}\text { Slope }{ }^{c} \\
\left(r^{2}\right)\end{array}$} & \multirow{2}{*}{$\begin{array}{l}\text { Mitotic indices } \\
(\%)(\text { mean } \pm \text { S.D. })^{d}\end{array}$} \\
\hline & & $\begin{array}{l}\text { Chromatid } \\
\text { type }\end{array}$ & $\begin{array}{l}\text { Chromosome } \\
\text { type }\end{array}$ & & & \\
\hline \multicolumn{7}{|l|}{ Induced $S 9$} \\
\hline $\begin{array}{l}\text { Solvent control } \\
\text { DMSO }(0.01 \mathrm{ml} / \mathrm{ml})\end{array}$ & 3.33 & 0.020 & 0.000 & $2.00 \pm 1.00$ & & $2.16 \pm 0.27$ \\
\hline $\begin{array}{l}\text { Benzidine } \\
100 \\
200 \\
400\end{array}$ & $\begin{array}{l}4.00 \\
6.67 \\
9.00\end{array}$ & $\begin{array}{l}0.030 \\
0.047 \\
0.050\end{array}$ & $\begin{array}{l}0.013 \\
0.010 \\
0.047\end{array}$ & $\begin{array}{l}4.33 \pm 0.58 * * \\
5.67 \pm 1.15 \\
9.00 \pm 1.00\end{array}$ & $\begin{array}{r}0.017 \\
\pm 0.002 \\
(0.91)\end{array}$ & $\begin{array}{l}1.55 \pm 0.26 * * \\
1.41 \pm 0.35 \\
1.25 \pm 0.45\end{array}$ \\
\hline $\begin{array}{l}\text { Positive control } \\
N \text {-acetylamino- } \\
\text { fluorene }\end{array}$ & 6.33 & 0.043 & 0.007 & $5.00 \pm 0.00 * *$ & & $1.50 \pm 0.41 * *$ \\
\hline $\begin{array}{l}\text { Uninduced } S 9 \\
\text { Solvent control } \\
\text { DMSO }(0.01 \mathrm{ml} / \mathrm{ml})\end{array}$ & 3.00 & 0.020 & 0.000 & $2.00 \pm 1.00$ & & $2.23 \pm 0.37$ \\
\hline $\begin{array}{l}\text { Benzidine } \\
100 \\
200 \\
400\end{array}$ & $\begin{array}{l}3.33 \\
6.33 \\
7.67\end{array}$ & $\begin{array}{l}0.026 \\
0.047 \\
0.056\end{array}$ & $\begin{array}{l}0.013 \\
0.017 \\
0.027\end{array}$ & $\begin{array}{l}4.00 \pm 1.00 * * \\
6.00 \pm 1.00 \\
8.33 \pm 0.58\end{array}$ & $\begin{array}{r}0.016 \\
\pm 0.002 \\
(0.89)\end{array}$ & $\begin{array}{l}1.69 \pm 0.50^{* *} \\
1.45 \pm 0.21 \\
1.29 \pm 0.28\end{array}$ \\
\hline $\begin{array}{l}\text { 4-Aminobiphenyl } \\
50 \\
100 \\
200\end{array}$ & $\begin{array}{l}4.67 \\
6.33 \\
8.33\end{array}$ & $\begin{array}{l}0.026 \\
0.053 \\
0.063\end{array}$ & $\begin{array}{l}0.020 \\
0.017 \\
0.043\end{array}$ & $\begin{array}{c}4.67 \pm 0.58^{* *} \\
6.33 \pm 1.15 \\
10.00 \pm 1.00\end{array}$ & $\begin{array}{r}0.039 \\
\pm 0.004 \\
(0.92)\end{array}$ & $\begin{array}{l}1.75 \pm 0.26^{*} \\
1.54 \pm 0.46^{* *} \\
1.17 \pm 0.30\end{array}$ \\
\hline $\begin{array}{l}\text { 4-Amino-4'-nitrobiphe } \\
50 \\
100 \\
200\end{array}$ & $\begin{array}{l}\text { yl } \\
4.33 \\
5.33 \\
6.67\end{array}$ & $\begin{array}{l}0.044 \\
0.047 \\
0.053\end{array}$ & $\begin{array}{l}0.000 \\
0.007 \\
0.017\end{array}$ & $\begin{array}{l}4.33 \pm 0.58 * * \\
5.33 \pm 0.58 \\
7.00 \pm 1.00\end{array}$ & $\begin{array}{r}0.024 \\
\pm 0.004 \\
(0.82)\end{array}$ & $\begin{array}{l}1.57 \pm 0.20 * * \\
1.48 \pm 0.35 \\
1.27 \pm 0.41\end{array}$ \\
\hline $\begin{array}{l}\text { 4-Aminostilbene } \\
25 \\
50 \\
100 \\
200\end{array}$ & $\begin{array}{l}7.00 \\
9.33 \\
12.33 \\
\text { cell toxi }\end{array}$ & $\begin{array}{l}0.053 \\
0.077 \\
0.080 \\
\mathbf{y}\end{array}$ & $\begin{array}{l}0.023 \\
0.030 \\
0.033\end{array}$ & $\begin{array}{c}7.67 \pm 0.58 * * \\
10.33 \pm 0.58 \\
11.00 \pm 1.00\end{array}$ & $\begin{array}{r}0.083 \\
\pm 0.016 \\
(0.72)\end{array}$ & $\begin{array}{l}1.51 \pm 0.25 * * \\
1.38 \pm 0.22 \\
1.11 \pm 0.31\end{array}$ \\
\hline $\begin{array}{l}4,4^{\prime} \text {-Diaminostilbene } \\
25 \\
100\end{array}$ & \multicolumn{3}{|c|}{$\begin{array}{l}\text { insufficent metaphase cells } \\
\text { cell toxicity - no division }\end{array}$} & & & $0.82 \pm 0.24 * *$ \\
\hline $\begin{array}{l}\text { 4-Amino-4'-nitrostilbe } \\
50 \\
100 \\
200\end{array}$ & $\begin{array}{l}5.33 \\
7.33 \\
7.00\end{array}$ & $\begin{array}{l}0.043 \\
0.060 \\
0.077\end{array}$ & $\begin{array}{l}0.010 \\
0.000 \\
0.000\end{array}$ & $\begin{array}{l}5.33 \pm 0.58 * * \\
6.00 \pm 1.00 \\
7.67 \pm 1.15\end{array}$ & $\begin{array}{r}0.026 \\
\pm 0.005 \\
(0.74)\end{array}$ & $\begin{array}{l}1.55 \pm 0.26 * * \\
1.43 \pm 0.14 \\
1.28 \pm 0.22\end{array}$ \\
\hline $\begin{array}{l}\text { Positive control } \\
N \text {-Acetylamino- } \\
\text { fluorene }\end{array}$ & 4.33 & 0.040 & 0.013 & $5.33 \pm 1.66 * *$ & & $1.43 \pm 0.17 * *$ \\
\hline
\end{tabular}

a Total chromatid and chromosome gaps per 100 cells at each concentration were recorded but not included as aberrations.

${ }^{b}$ Cells with at least 1 aberration. Results are for 3 animals at each concentration ( 100 cells /animal from 2 culture tubes).

c Slope \pm S.D. and correlation coefficent $\left(r^{2}\right)$ for the aberrant cell concentration-response curve for each compound.

d Lowest dose for which the mean is significantly greater than its negative control using Dunnett's test is indicated by $P<0.05$ and $* * P<0.01$. 
1992) in which Salmonella strains were used and $4,4^{\prime}$-diaminostilbene was found to be weakly mutagenic.

CA frequencies and MI values for the lymphocytes of mice following i.p. administration of benzidine and the 5 related aromatic amines were observed at a single dose of $25 \mathrm{mg} / \mathrm{kg}$ for an initial comparison of their in vivo genotoxicity. This dose was based upon the previous dosegenotoxicity relationships found for benzidine in our in vivo CA bone-marrow cell study (Sinsheimer et al., 1992). The fixation times used for the lymphocyte cultures in this study are the same as those previously employed in our epoxides study (Das et al., 1993). DeBoer et al. (1977) found for murine lymphocytes that similar fixation times resulted in predominantly 1 st division metaphase cells. For a more definitive in vivo genotoxicity comparison, an optimal fixation time should be established for these compounds and the comparison should be based upon a dose-response evaluation for each compound (Preston et al., 1987).

In the present in vivo CA assay, all the compounds with the exception of 4-aminostilbene had a significant increase in the percentage of abnormal cells at $25 \mathrm{mg} / \mathrm{kg}$ when compared to the negative control $(1.67 \pm 0.58 \%)$. 4-Aminostilbene could not be compared at this concentration because of cell toxicity but at $10 \mathrm{mg} / \mathrm{kg}$ it had a higher percentage of CA $(7.00 \pm 1.00 \%)$ than any of the other amines at $25 \mathrm{mg} / \mathrm{kg}(3.00 \pm 1.00$ $5.67 \pm 1.16 \%$ ), where for these values $4,4^{\prime}$-diaminostilbene had the least and 4-amino-4'nitrostilbene had the greatest genotoxicity. These results are in comparison to $11.00 \pm 1.00 \%$ for $\mathrm{CP}$, the positive control. The most frequent aberrations were chromatid breaks. Benzidine and all 5 aromatic amines produced a significant decrease in MI compared to the negative solvent control.

The results of the present studies on cultured mouse lymphocytes subsequent to either in vivo or in vitro exposure to the aromatic amines were compared to our previous in vivo genotoxicity studies of the same amines (Sinsheimer et al., 1992). In general, there is an increase in observable results for the in vivo lymphocyte assay compared to the in vivo bone-marrow cell examina- tion for CA. That is, CA values for $25 \mathrm{mg} / \mathrm{kg}$ i.p. doses in the lymphocyte assay are about twice those of the bone-marrow cell results at this dose. These results for the non-dividing lymphocytes in comparison to rapidly dividing bone-marrow cells were unexpected.

The relative order of in vitro lymphocyte genotoxicity is 4-aminostilbene $>4$-aminobiphenyl $>$ 4-amino-4' -nitrostilbene $=4$-amino-4' nitrobiphen$\mathrm{yl}>$ benzidine. Thus, 4-aminostilbene is the most genotoxic of the present series of amines when the same lymphocyte-CA end point was used in vitro and in vivo. This was not the case when Salmonella strains were used for the in vitro evaluation of these amines. Moreover, the present study is in agreement with the pronounced in vivo genotoxicity of 4-aminostilbene as measured by its CA effects to the bone-marrow cells of mice.

\section{Acknowledgements}

This investigation was supported by grant R01 ES 05047 from the National Institute of Environmental Health Sciences, DHHS.

\section{References}

Asquith, J.C., L.K. Hogan, J.N. Fullwood, J.D. Rae and D.J. Kirkland (1985) A comparison of the chromosome damaging effects, in cultured human lymphocytes, of benzidine (BZD) and 4,4'-diaminoterphenyl (DAT) in presence of Aroclor induced and uninduced rat liver S9, in: J.M. Parry and C.F. Arlett (Eds.), Comparative Genetic Toxicology, The Second UKEMS Collaborative Study, United Kingdom, VCH, Deerfield Beach, FL, pp. 355-362.

Carrano, A.V., and A.T. Natarajan (1988) Considerations for population monitoring using cytogenetic techniques, Mutation Res., 204, 379-406.

Das, L., S.K. Das, E.H.Y. Chu and J.E. Sinsheimer (1993) Chromosomal aberrations in mouse lymphocytes exposed in vivo and in vitro to aliphatic epoxides, Mutation Res., $299,19-24$.

Davisson, M.T., and E.C. Akeson (1987) An improved method for preparing $\mathrm{G}$-banded chromosomes from mouse peripheral blood, Cytogenet. Cell Genet., 45, 70-74.

DeBoer, P., P.P.W. Van Buul, R. Van Beek, F.A. Van Der Hoeven and A.T. Natarajan (1977) Chromosomal radiosensitivity and karyotype in mice using cultured peripheral blood lymphocytes and comparison with this system in man, Mutation Res., 42, 379-394.

Galloway, S.M., P.K. Berry, W.W. Nichols, S.R. Wolman, 
K.A. Soper, P.D. Stolley and P. Archer (1986) Chromosome aberrations in individuals occupationally exposed to ethylene oxide, and in a large control population, Mutation Res., 170, 55-74.

Haley, T.J. (1975) Benzidine revisited; A review of the literature and problems associated with the use of benzidine and congeners, Clin. Toxicol., 8, 13-42.

Kligerman, A.D., J.L. Wilmer and G.L. Erexson (1982) The use of rat and mouse lymphocytes to study cytogenetic damage after in vivo exposure to genotoxic agents, in: B.H. Bridges, B.E. Butterworth and I.B. Weinstein (Eds.), Banbury Report 13; Indicators of Genotoxic Exposure, Cold Spring Harbor Laboratory, Cold Spring Harbor, NY, pp. 277-291.

Lambert, B., A. Lindblad, K. Holmberg and D. Francesconi (1982) The use of sister chromatid exchanges to monitor human populations for exposure to toxicologically harmful agents, in: S. Wolff (Ed.), Sister Chromatid Exchange, Wiley, New York, pp. 149-182

Maron, D.M., and B.N. Ames (1983) Revised methods for the Salmonella mutagenicity test, Mutation Res., 113, 173-215.

Messerly, E.A., J.E. Fekete, D.R. Wade and J.E. Sinsheimer (1987) Structure-mutagenicity relationships of benzidine analogues, Environ. Mol. Mutagen., 10, 263-274.

Norppa, H., K. Hemminki, M. Sorsa and H. Vainio (1981) Effect of monosubstituted epoxides on chromosome aberrations and SCE in cultured human lymphocytes, Mutation Res., 91, 243-250.
Preston, R.J., B.J. Dean, S. Galloway, H. Holden, A.F. McFee and M. Shelby (1987) Mammalian in vivo cytogenetic assays, Analysis of chromosome aberrations in bone marrow cells, Mutation Res., 189, 157-165.

Rithdech, K., W.W. Au, V.M.S. Ramanujam, E.B. Whorton Jr. and M.S. Legator (1987) Induction of chromosome aberrations in lymphocytes of mice after subchronic exposure to benzene, Mutation Res., 188, 135-140.

Sasiadek, M., H. Norppa and M. Sorsa (1991) 1,3-Butadiene and its epoxide induces sister-chromatid exchanges in human lymphocytes in vitro, Mutation Res., 261, 117-121.

Sharief, Y., A.M. Brown, L.C. Backer, J.A. Campbell, B. Westbrook-Colling, A.G. Stead and J.W. Allen (1986) Sister chromatid exchange and chromosome aberration analyses in mice after in vivo exposure to acrylonitrile, styrene, or butadiene monoxide, Environ. Mutagen., 8, 439-448.

Sinsheimer, J.E., B.H. Hooberman, S.K. Das, M.D. Brezzell and Z. You (1992) The in vivo and in vitro genotoxicity of aromatic amines in relationship to the genotoxicity of benzidine, Mutation Res., 268, 255-264.

You, Z., M.D. Brezzell, S.K. Das, M.E. Espadas-Torre, B.H. Hooberman and J.E. Sinsheimer (1993) Ortho-substituent effects on the in vitro and in vivo genotoxicity of benzidine derivatives, Mutation Res., 319, 19-30.

Zavon, M.R., V. Hoegg and E. Bingman (1973) Benzidine exposure as a cause of bladder tumors, Arch. Environ. Health, 27, 1-8. 